Vol. 3, No. 2, 2021

https://doi.org/10.23939/jtbp2021.02.076

Serhiy Bula, Mariana Kholod, Nazarii Viter

\title{
NUMERICAL ANALYSIS FOR COMPRESSED CERAMIC HOLLOW BRICK MASONRY COLUMNS STRENGTHENED WITH GFRP MESHES
}

\author{
Department of Building Structures and Bridges, \\ Lviv Polytechnic National University \\ serhii.s.bula@lpnu.ua
}

(C) Bula S., Kholod M., Viter N., 2021

This article presents the analysis of obtained experimental results for the study of masonry columns which have been strengthened by GFRP confinement after high-level axial compression loading. Ceramic hollow-brick middle-scale models were investigated regarding assumed testing program. The basics of experimental studies were briefly described in the paper. Theoretical study was performed to compare experimental and theoretical values. Such numerical analysis helps to evaluate the possibility to use the existing standard 's approaches for calculating bearing capacity of strengthened by GFRP jacketing ceramic brick columns which were subjected to the high axial loading. Theoretical results areratheraligned with experimental data. Some conclusions were provided in terms of usability the analytical model provided standards and other scientists. Addressing to the further investigation and research problems were performed.

Keywords: masonry, confinement, GFRP mesh, strengthening, effective confining pressure, design compressive strength.

\section{Introduction}

Strengthening of compressed masonry structures by GFRP (Glass Fiber-Reinforced Polymer) meshes gains popularity due to its advantages against more typical methods (e.g. steel framing and concrete jacketing). However, polymer composites are rather new material and needs to be more investigated under different limit states and conditions.

Since the spread of composite materials from the military\&space industry to the construction industry (1980s), a lot ofresearcheshave been provided to make possible to formulate the basic design provisions and approaches to design composite materials in structures. However, at present in Europe there is no single regulatory document (e.g.Eurocode) that would regulate the usage of FRP (fiber reinforced polymers) systems. The main recommendations for the use of FRP reinforcement in structures are given in the national standards of Japan (JSCE, 1997), Canada (CSA-S806, 2002), Italy (CNR-DT 200 R1/2013, 2013), USA (ACI 440.1R, 2006). The main provisions of these recommendations are highlighted in the reports of the International Reinforced Concrete Federation (FIB) regarding usage of FRP reinforcement (Matthys, \& Fib Working Group, 2019). These regulations are supplemented and continued in subsequent editions.

Recently publishedpapers (Yilmazet al., 2013), (Cascardi et al., 2020), (Borri et al., 2012), (Valdeset al., 2015), (Witzany\&Zigler, 2016) contain calculation methods analysis for the FRP confined 
masonry columns. Experimental studiesprovided by author in scope of the tests were verified accordingtotheexisting analytical models.As result, usability of suggested approaches was discussed and accordance with experimental part was reported as well. Also, valuableinputs were provided by different scientists (Minafo et al., 2017), (Micelli et al., 2004), (Rao and Pavan, 2015), (Krevaikas and Triantafillou, 2005), (Lignova et al., 2014) in terms of analytical prediction of FRP-confined masonry structures` behavior. However, theoretical investigation for hollow ceramic brick columns strengthenedwith GFRP after high level loading was not provided previously.

\section{Article purpose}

The purpose of this article is to evaluate existing design approaches for masonry ceramic brick columns structural analysis after high-level loading and further decompression with FRP strengthening. Also, comparative analysis between experimental and theoretical data will be performed.

\section{Experimental program}

Specimens' construction, strengthening techniques and testing program were reported by authors previously in details (Bula \& Kholod, 2020). The specimen`s parameters were as follow: height $\sim 800$ $\mathrm{mm}$, cross-section $-250 \mathrm{~mm} \times 250 \mathrm{~mm}$, mortar thickness $-\sim 10 \mathrm{~mm}$. As specimen`s material the hollow ceramic bricks were used with unit dimensions $250 \mathrm{~mm} \times 120 \mathrm{~mm} \times 88 \mathrm{~mm}$. Bonding mortar was manufactured in-site by mixing Portland cement and sand with a mass ratio of (1:6). Average (10 tests) compressive strength reported as $f_{m}=5.70 \mathrm{MPa}$ for mortar and $f_{b}=6.31 \mathrm{MPa}$ for brick. Reinforcing system included the glass fiber meshMapegrid G120(TM "Mapei") and two-component ready-mixed fiber-reinforced repair mortar. Basing on producer`s data mesh properties were taken as follows: mesh size $-12.7 \mathrm{~mm} \times 12.7 \mathrm{~mm}$; tensile strength $-1300 \mathrm{MPa}$; elastic modulus $72 \mathrm{GPa}$; ultimate strain $-1.8 \%$.

Masonry columns have been tested under axial compression provided by means of the hydraulic press. Specimens were axially loaded with a 10-min pause on every loading step to achieve full crack development and stabilization. Longitudinal and transversal deformations were measured by mechanical strain gages during compression test. Two columns ("s" series) were loaded up to failure as control samples. The other two columns ("d" series) were subjected to $\sim 80 \%$ of ultimate loading and staged for $20 \mathrm{~min}$. After that the specimens were fully unloaded and confined with continuous GFRP-mesh wrapping. Preparation and strengthening application procedure was realized in accordance with producer recommendations.

\section{Numerical analysis}

Numerical analysis was provided basing on Italian National Standard (CNR-DT 200 R1/2013) and on some related analytical models suggested by authors in theirresearch(Faella et. al., 2011), (Corradi et al., 2007), (Di Ludovico et. al., 2010).

CNR standard suggests using the following equation for members confined with FRP subjected to a lateral confining pressure $f_{l}$

$$
f_{m c d}=f_{m d}\left[1+k^{\prime}\left(\frac{f_{l, e f f}^{\prime}}{f_{m d}}\right)^{\alpha_{1}}\right],
$$

where $f_{m c d}$ - design compressive strength of the FRP member; $f_{m d}$ - design compressive strength of the unconfined masonry; $k^{\prime}$ - non-dimensional coefficient; $f_{l, \text { eff }}$ - effective confining pressure; $\alpha_{1}$ - coefficient equal to 0.5 if further experimental data is not available. 
Non-dimensional coefficient $k$ ' is supposed to define according the equation:

$$
k^{\prime}=\alpha_{2}\left(\frac{g_{m}}{1000}\right)^{\alpha_{3}},
$$

where $g_{m}$ - masonry mass-density expressed as $\mathrm{kg} / \mathrm{m}^{3} ; \alpha_{1}$ and $\alpha_{2}$ - coefficient equal to 1.0 if further experimental data is not available.

The effective confining pressure is defined as a function of the coefficient of efficiency:

$$
f_{l, e f f}=k_{\text {eff }} f_{l}=k_{H} k_{V} f_{l},
$$

where $k_{H}$ - horizontal coefficient of efficiency (depends on cross-section geometry); $k_{V}$ - vertical coefficient of efficiency (depends on wrapping type); $f_{l}$ - confining pressure caused by FRP material;

For a continuous confinement, $k_{v}$ is equal to 1 . The following equations should be used for $f_{l}, k_{H}, k_{V}$ values in case of rectangular (square) cross-section and continuous FRP reinforcement:

$$
f_{l}=2 \frac{t_{f} E_{f}}{\max \{b, h\}} \varepsilon_{f_{d, \text { rid }}},
$$

where $t_{f}$ - FRP thickness; $E_{f}-$ FRP modulus of elasticity; $b, h$ - columns cross-section dimensions; $\varepsilon_{f d, \text { rid }}-$ reduced design strain for FRP reinforcement.

The horizontal coefficient of efficiency is given by the ratio between the confined area and the total area of the masonry column, $A_{m}$, as follows:

$$
k_{H}=1-\frac{b^{\prime 2}+h^{\prime 2}}{3 A_{m}} .
$$

Dimensions mentioned in equation (5) are indicated in Fig. 1.

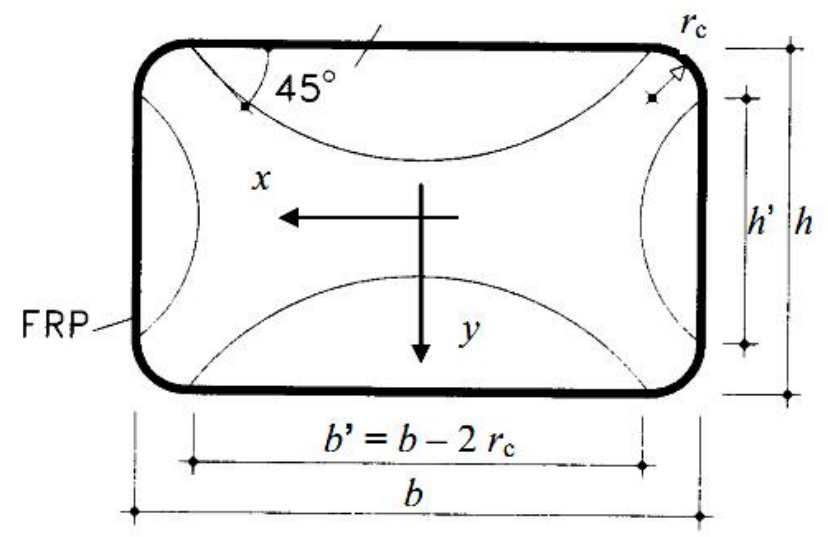

Fig. 1. Confinement of rectangular sections externally wrapped with FRP

The reduced design strain for FRP reinforcement can be written as follows:

$$
\varepsilon_{f_{d, r i d}}=\min \left\{\frac{\eta_{\alpha} \varepsilon_{f k}}{\gamma_{f}} ; 0.004\right\},
$$

where $\eta_{a}$ - the environmental conversion factor for different exposure conditions; $\varepsilon_{f k}-$ ultimate strain for FRP mesh (technical data depends on mesh type);

$\gamma_{f}$ - partial factors for FRP mesh. For the ultimate limit state, the value assigned to the partial factor of FRP materials is equal to $1.10 ; 0.004$ - conventional strain limit. 
Numerical investigationshave been performed according to the equations listed above. The initial data sheet for masonry and GFRP reinforcement is given in Table 1.Compressive strength forunconfined masonry was defined by experimental data. Reinforcement characteristics were taken from producer's data sheet. Design factors were assumed according to CNR tables.

Table 1

Masonry/ReinforcementDataSheet

\begin{tabular}{|l|c|c|c|}
\hline \multicolumn{1}{|c|}{ Data } & Symbol & Value & Units \\
\hline $\begin{array}{l}\text { Design compressive strength of the unconfined masonry } \\
\text { (Bula \& Kholod, 2020) }\end{array}$ & $f_{m d}$ & 3.02 & {$[\mathrm{MPa}]$} \\
\hline Masonry mass-density & $g_{m}$ & 1710 & {$\left[\mathrm{~kg} / \mathrm{m}^{3}\right]$} \\
\hline Equivalent thickness of dry mesh (GFRP) & $t_{f}$ & 0.024 & {$[\mathrm{~mm}]$} \\
\hline Modulus of elasticity (GFRP) & $E_{f}$ & 72000 & {$[\mathrm{MPa}]$} \\
\hline Elongation at failure & $\varepsilon_{f k}$ & 1.8 & {$[\%]$} \\
\hline Masonry column dimensions & $b x h$ & $250 \times 250$ & {$[\mathrm{~mm}]$} \\
\hline Column's fillet & $r_{c}$ & 30 & {$[\mathrm{~mm}]$} \\
\hline Partial factor for GFRP mesh & $\gamma_{f}$ & 1.1 & - \\
\hline Environmental conversion factor & $\eta_{a}$ & 0.75 & - \\
\hline
\end{tabular}

The design compressive strength for confined samples and comparison with experimental data are provided in Table 2. The mean value for experimental samples in series is shown. The theoretical values have been calculated for different analytical models and reported below.

Table 2

\section{Comparison between experimental and theoretical results}

\begin{tabular}{|c|c|c|c|c|c|}
\hline $\begin{array}{l}\text { Strengthened } \\
\text { samples } \\
\text { "s" series }\end{array}$ & $\begin{array}{c}f_{\text {mcd }}(E X P, \text { peak }) \\
\text { mesh failure } \\
\text { criteria } \\
{[\mathrm{MPa}]}\end{array}$ & $\begin{array}{c}f_{m c d}(\text { THEOR }) \\
(\mathrm{CNR} \text { DT } \\
200 \mathrm{R} 1 / 2013) \\
{[\mathrm{MPa}]}\end{array}$ & $\begin{array}{c}f_{m c d}(T H E O R) \\
\text { (Faella et al.) } \\
\text { [MPa] }\end{array}$ & $\begin{array}{c}f_{m c d}(T H E O R) \\
\text { (Corradi et al.) } \\
{[\mathrm{MPa}]}\end{array}$ & $\begin{array}{c}f_{m c d}(T H E O R) \\
\text { (Di Ludovico et al.) } \\
{[\mathrm{MPa}]}\end{array}$ \\
\hline $\begin{array}{c}\text { Compressive } \\
\text { strength }\end{array}$ & 4.2 & 3.57 & 4.9 & 3.2 & 3.1 \\
\hline $\begin{array}{l}\text { EXP } \\
\text { THEOR } \\
\text { ratio }\end{array}$ & - & 1.17 & 0.85 & 1.31 & 1.35 \\
\hline
\end{tabular}

\section{Conclusions}

In this article theoretical evaluation was performed for the confined middle-scale masonry structures produced with hollow ceramic bricks after subjecting them to a high level (up to $80 \%$ of ultimate strength) compression. Numerical investigation shows quite good compliance with experimental results (see Table 2). However, calculations by (Di Ludovico et. al., 2010) and (Corradi et al., 2007) give more conservative outcome (31-35\%) comparing with the experimental data. Analytical model by (Faella et. al., 2011) reveals $15 \%$ overestimating of the theoretical compressive strength value. The closest agreement was receivedaccording to (CNR-DT 200 R1/2013, 2013). Such versatile theoretical results could be explained by specific hollow ceramic brick behavior, which is not fully accounted in investigated analytical models. 
In general, approach proposed in CNR can be used for predicting of the compressive strength for corresponding "damages/material" combination. Although, more detailed FEM model analysis and probably existing analytical models calibration needs to be provided in further research for correspondent combination.

Acknowledgments: All materials used for strengthening of specimens in this study have been granted by Mapei,UA.

\section{References}

JSCE. (1997). Recommendation for design and construction of concrete structures using continuous fiber reinforcing materials. Research Committee on Fiber Reinforcing Materials, Japan Society of Civil Engineers, Tokyo. URL: https://www.e-periodica.ch/cntmng?pid=bse-re-003:1999:81::23

Standard, C. S. A. (2002). Design and construction of building components with fibre-reinforced polymers. S806-02, Canadial Standards Association. URL: http://www.ictturkey.com/assets/images/can.csa.s806-02.pdf

CNR-DT 200 R1/2013. Guide for the Design and Construction of Externally Bonded FRP Systems for Strengthening Existing Structures, National Research Council, Rome, Italy. p. 154. URL: https://www.cnr.it/ en/node $/ 2638$

ACI (2006), ACI 440.1R Guide for the design and construction of concrete reinforced with FRP bars, ACI Committee 440, American Concrete Institute (ACI). URL: https://www.concrete.org/store/productdetail.aspx? ItemID $=440115$

Matthys, S., \& Fib Working Group. (2019). Externally applied FRP reinforcement for concrete structures (Vol. 90). International Federation for Structural Concrete. URL: https://biblio.ugent.be/publication/8657278

Yilmaz, I., Mezrea, P. E., Ispir, M., Binbir, E., Bal, I. E., \& Ilki, A. (2013, December). External confinement of brick masonry columns with open-grid basalt reinforced mortar. In Proceedings of the fourth Asia-Pacific conference on FRP in structures (APFIS 2013), Melbourne, Australia (pp. 11-13). URL: https://researchbank. swinburne.edu.au/items/5036e8bb-dd27-489a-9321-36801c936868/1/PDF\%20\%28Published\% 20version\%29.pdf

Cascardi, A., Lerna, M., Micelli, F., \& Aiello, M. A. (2020). Discontinuous FRP-confinement of masonry columns. Frontiers in Built Environment, 5, 147. URL: https://doi.org/10.3389/fbuil.2019.00147

Borri, A., Castori, G., \&Corradi, M. (2011). Masonry columns confined by steel fiber composite wraps. Materials, 4(1), 311-326. URL: https://doi.org/10.3390/ma4010311

Valdes, M., Concu, G., \& De Nicolo, B. (2015). FRP strengthening of masonry columns: experimental tests and theoretical analysis. In Key Engineering Materials (Vol. 624, pp. 603-610). Trans Tech Publications Ltd. URL: http://dx.doi.org/10.4028/www.scientific.net/KEM.624.603

Witzany, J., \& Zigler, R. (2016). Stress state analysis and failure mechanisms of masonry columns reinforced with FRP under concentric compressive load. Polymers, 8(5), 176. URL: https://doi.org/10.3390/polym8050176

Minafò, G., D'Anna, J., Cucchiara, C., Monaco, A., \& La Mendola, L. (2017). Analytical stress-strain law of FRP confined masonry in compression: Literature review and design provisions. Composites Part B: Engineering, 115, 160-169. URL: https://doi.org/10.1016/j.compositesb.2016.10.019

Micelli, F., De Lorenzis, L., \& La Tegola, A. (2004). FRP-confined masonry columns under axial loads: experimental results and analytical model. Masonry Int. J, 17, 95-108. URL:https://www.researchgate.net/ publication/284674924_FRP-confined_masonry_columns_under_axial_loads_Experimental_results_and_analytical_model

Rao, K. N., \& Pavan, G. S. (2015). FRP-confined clay brick masonry assemblages under axial compression: Experimental and analytical investigations. Journal of Composites for Construction, 19(4), 04014068. URL: https://ascelibrary.org/doi/abs/10.1061/\%28ASCE\%29CC.1943-5614.0000525

Krevaikas, T. D., \& Triantafillou, T. C. (2005). Masonry confinement with fiber-reinforced polymers. Journal of Composites for Construction, 9(2), 128-135. URL: http://dx.doi.org/10.1061/(ASCE)1090-0268(2005)9:2(128)

Lignola, G. P., Angiuli, R., Prota, A., \& Aiello, M. A. (2014). FRP confinement of masonry: analytical modeling. Materials and structures, 47(12), 2101-2115. URL: http://dx.doi.org/10.1617/s11527-014-0323-6

Bula, S., \&Kholod, M. (2020, September). Experimental Study of Compressed Ceramic Hollow Brick Masonry Structures Strengthened with GFRP Meshes. In International Scientific Conference EcoComfort and Current Issues of Civil Engineering (pp. 71-78). Springer, Cham. URL: http://dx.doi.org/10.1007/978-3-030-57340-9_9

Faella, C., Martinelli, E., Paciello, S., Camorani, G., Aiello, M. A., Micelli, F., \& Nigro, E. (2011). Masonry columns confined by composite materials: Experimental investigation. Composites Part B: Engineering, 42(4), 692704. URL: http://dx.doi.org/10.1016/j.compositesb.2011.02.001 
Corradi, M., Grazini, A., \& Borri, A. (2007). Confinement of brick masonry columns with CFRP materials. Composites science and technology, 67(9), 1772-1783. URL: http://dx.doi.org/10.1016/j.compscitech.2006.11.002

Di Ludovico, M., D’Ambra, C., Prota, A., \&Manfredi, G. (2010). FRP confinement of tuff and clay brick columns: Experimental study and assessment of analytical models. Journal of Composites for Construction, 14(5), 583-596. URL: http://dx.doi.org/10.1061/(ASCE)CC.1943-5614.0000113

С. С. Була, М. І. Холод, Н. В. Вітер

Національний університет “Львівська політехніка", кафедра будівельних конструкцій та мостів

\section{ЧИСЕЛЬНИЙ АНАЛІЗ СТИСНУТИХ ЦЕГЛЯНИХ КОНСТРУКЦІЙ З ПУСТОТІЛОЇ КЕРАМІЧНОЇ ЦЕГЛИ, ЩО БУЛИ ПОСИЛЕНІ СІТКАМИ ІЗ СКЛОВОЛОКНА}

() Була С. С., Холод М. І., Вітер Н. В., 2021

Наведено чисельний аналіз експериментальних результатів, що отримані в результаті випробувань стиснутих цегляних конструкцій виконаних із пустотілої керамічної цегли, що піддавалися центральному стиску до рівня 80 \% від руйнівного, розвантажувалися та підсилювалися за допомогою сіток із скловолокна.

На цей момент у Європі (як і в Україні) немає єдиного нормативного документа, що регламентує використання композитних матеріалів під час підсилення конструкцій. Основні рекомендації щодо застосування FRP армування у залізобетонних конструкціях наведено у національних нормах Японії, Канади, США. Основні положення цих рекомендацій також висвітлено у звітах Міжнародної федерації зі залізобетону (FIB) щодо використання FRP-армування.

На цей момент багато науковців проводять дослідження підсилених композитними матеріалами цегляних колон за різних рівнів навантаження, типу цегляної кладки, типу матеріалу підсилення. Отримані експериментальні результати верифікуються з теоретичними положеннями, що викладені у національних нормах окремих країн.

Проведено аналіз експериментальних результатів на основі італійських національних норм та на основі методик розрахунку, що їх запропонували деякі італійські науковці. У результаті проаналізовано збіжність експериментальних результатів 3 теоретичними засадами розрахунку (за чотирма методиками). Отримані збіжності експериментальних та теоретичних даних показали, що досліджувані поєднання рівня навантажень та типу кладки не повністю враховані у розрахункових підходах та потребують уточнення. Завданням таких досліджень $\epsilon$ створення уточнених розрахункових моделей та пропозицій до розрахунку таких конструкцій.

Ключові слова: чисельний аналіз, цегляні конструкції, сітки із скловолокна, композитні матеріали, підсилення, міцність кладки на стиск. 